\title{
EVALUASI EFEKTIVITAS DAN EFISIENSI KINERJA PEMERINTAH DESA KALIKURMO KECAMATAN BRINGIN KABUPATEN SEMARANG PERIODE 2016-2018
}

\author{
EVALUATION OF EFFECTIVENESS AND EFFICIENCY OF KALIKURMO VILLAGE \\ GOVERNMENT PERFORMANCE, BRINGIN SUB-DISTRICT, SEMARANG DISTRICT, \\ PERIOD 2016-2018
}

\author{
Ichda Apriliana Lutfi*), Della Eka Safitri, Mega Rukmanawati, Saiful Anwar, Nur Kabib \\ Program Studi Akuntansi Syariah, Fakultas Ekonomi dan Bisnis Islam, IAIN Salatiga \\ Jatisari RT 03/02, Kopen, Teras, Boyolali \\ *alamat korespondensi : ichdaaprilianalutfi@gmail.com
}

(Tanggal Submission: 9 April 2020, Tanggal Accepted: 27 April 2020)

\begin{abstract}
ABSTRAK
Kegiatan penelitian dan pengabdian kepada masyarakat ini bertujuan untuk menganalisis kinerja pemerintah desa Kalikurmo tahun 2016-2018. Hasil kajian ini menjadi dasar untuk melakukan evaluasi demi terciptanya peningkatan efektifitas dan efisiensi kinerja perangkat desa dalam hal pelayanan kepada masyarakat. Metode yang digunakan pada kegiatan ini adalah metode deskriptif kualitatif menggunakan rasio efektivitas dan efisiensi untuk mengukur kinerja pemerintah desa Kalikurmo. Data primer diperoleh melalui observasi. Data penunjang diperoleh dari Laporan Realisasi Anggaran pemerintah desa Kalikurmo. Hasil kegiatan menunjukkan bahwa rasio efektivitas anggaran pendapatan tahun 2016-2018 kinerja pemerintah desa Kalikurmo Kecamatan Bringin Kabupaten Semarang sangat efektif dengan prosentase 100\%. Sedangkan untuk rasio efisiensi anggaran belanja tahun 2016-2018 pemerintah desa Kalikurmo Kecamatan Bringin Kabupaten Semarang dinilai kurang efisien dengan kisaran 90\%-100\%. Hal ini disebabkan pemerintah desa Kalikurmo terlalu boros dalam menggunakan anggaran belanja desa. Berdasarkan hal tersebut, disimpulkan sebuah rekomendasi untuk melakukan penghematan anggaran belanja dalam rangka meningkatkan efisiensi pembelanjaan dana desa.
\end{abstract}

Kata Kunci : Laporan Realisasi Anggaran, Rasio Efektivitas, Rasio Efisiensi

\section{PENDAHULUAN}

Provinsi, kabupaten atau kota dan desa adalah kategori daerah otonom mulai dari tingkat teratas sampai terbawah yang memilki kewenangan untuk mengurus rumah tangganya sendiri. Undang-undang Nomor 32 tahun 2004 tentang Pemerintah Daerah, desa adalah kesatuan masyarakat hukum yang memiliki batas-batas wilayah yang berwenang untuk mengatur dan mengurus kepentingan masyarakat setempat, berdasarkan asal-usul dan adat istiadat tempat yang diakui dan dihormati dalam sistem Pemerintahan Negara Kesatuan Republik Indonesia (Indonesia, 2004).

Kinerja keuangan pemeritah adalah tingkatan dari pencapaian suatu hasil kerja dalam bidang keuangan daerah yang terdiri dari penerimaan dan belanja daerah yang menggunakan sistem keuangan yang ditetapkan melalui suatu ketentuan atau kebijakan perundang-undangan selama satu periode anggaran. Bentuk dari pengukuran kinerja tersebut berupa rasio keuangan yang terbentuk dari sistem 
laporan pertanggungjawaban kepala daerah berupa perhitungan APBD.(Boedi, 2012).

Otonomi daerah di Indonesia yang berdasarkan pada Undang-Undang Nomor 32 Tahun 2004 tentang Pemerintah Daerah dan Undang-Undang Nomor 33 Tahun 2004 tentang Perimbangan Keuangan antara Pemerintah Pusat dan Daerah, yang membuka peluang yang luas bagi daerah untuk mengembangkan dan membangun daerahnya sesuai dengan kebutuhan dan prioritasnya masing-masing. Dengan diberlakukannya kedua undang-undang tersebut maka akan membawa konsekuensi untuk daerah dalam upaya meningkatkan kesejahteraan dan pelayanan umum kepada masyarakat.(Mamuaja, 2016)

Desa merupakan daerah otonom terendah, secara otomatis akan menjadi objek dari berlangsungnya sistem desentralisasi fiskal yang dapat diperoleh dari pemerintah pusat dan pemerintah daerah. Pengelolaan keuangan desa diturunkan dalam bentuk kebijaksanaan desa yang terdiri dari Anggaran Pendapatan dan Belanja Desa (APBDesa). APBDesa adalah peraturan desa yang digunakan untuk memuat sumber-sumber penerimaan dan alokasi pengeluaran desa dalam kurun waktu satu tahun (Yunianti, 2015).

Permendagri No. 37 tahun 2007, Anggaran Pendapatan dan Belanja Desa (APBDesa) adalah rencana keuangan tahunan pemerintahan desa yang dibahas dan disetujui bersama oleh Pemerintah Desa dan Badan Permusyawaratan Desa (BPD), dan ditetapkan dengan peraturan desa. Definisi anggaran pendapatan dan belanja daerah juga merupakan daftar yang memuat rincian dari penerimaan daerah dan pengeluaran belanja daerah selama satu tahun. APBD merupakan rencana kerja kegiatan pemerintah daerah yang dituangkan dalam bentuk angka dan menunjukan adanya sumber penerimaan yang merupakan target minimal dan beban yang merupakan batas maksimal untuk suatu periode anggaran.(Roland Gerald Tooy, David Paul Elia Saerang, 2016).

Efisiensi dan Efektivitas dapat melihat sejauh mana suatu keadaan keuangan mempergunakan atau memanfaatkan sumbersumber daya yang ada secara ekonomis, hemat atau efisien dan dilakukan secara tepat dan memenuhi sasaran atau efektif serta hasil yang dicapai memiliki rasionalitas terhadap penggunaan sumber-sumber yang ada atau produktivitas. Efisiensi atau daya guna) merupakan perbandingan antara output dengan input.

Efisiensi adalah sesuatu yang berkaitan dengan barang dan jasa yang menghasilkan sebuah kegiatan atau aktifitas dengan sumber daya yang digunakan. Suatu organisasi, kegiatan atau program dapat dikatakan efisien apabila mampu menghasilkan output tertentu dengan input yang serendah-rendahnya, atau dengan input tertentu yang mampu menghasilkan output sebesarbesarnya (spending well).

Efektivitas pada dasarnya berkaitan dengan pencapaian suatu tujuan atau target dari kebijakan (hasil guna). Efektivitas merupakan relasi antara keluaran dengan tujuan atau sasaran yang harus dicapai. Kegiatan operasional akan dikatakan efektif apabila proses dari kegiatan mencapai tujuan dan sasaran akhir kebijakan (spending wisely) (Mardiasmo, 2002). Penilaian Kinerja Anggaran Pendapatan dan Belanja Daerah (APBD) merupakan suatu sasaran yang diharapkan sebagai fungsi dari belanja, Standar pelayanan diharapkan dan diperkirakan biaya satuan komponen kegiatan yang bersangkutan, bagian pendapatan APBD yang membiayai belanja administrasi umum, belanja operasi dan pemeliharaan dan belanja modal/pembangunan (Sinambela \& Pohan, 2016).

Anggaran pemerintah terkait dengan proses penentuan jumlah alokasi dana untuk tiaptiap program dan aktivitas dalam satuan moneter yang menggunakan dana milik masyarakat. Anggaran publik merupakan alat perencanaan sekaligus alat pengendalian. Anggaran sebagai alat perencanaan dapat mengindikasikan target yang harus dicapai oleh pemerintah, sedangkan anggaran sebagai alat untuk pengendalian mengindikasikan alokasi sumber dana publik yang disetujui legislatif untuk dibelanjakan.(Basariyah, 2017) Pengukuran kinerja sangat dibutuhkan untuk menilai akuntabilitas organisasi dan manajer dalam menghasilkan pelayanan publik yang lebih baik. Akuntabilitas bukan hanya sekedar kemampuan yang menunjukkan bagaimana uang publik tersebut telah dibelanjakan secara efektif, efisiensi, dan ekonomis. Pengukuran kinerja yang digunakan sebagai dasar untuk melakukan penilaian kinerja, yaitu untuk menilai berhasil atau tidaknya suatu 
organisasi dalam program atau kegiatan.(Ropa, 2016).

Laporan realisasi anggaran merupakan salah satu dari komponen laporan keuangan pemerintah yang menyiapkan informasi mengenai realisasi anggaran dalam suatu periode tertentu. Laporan Realisasi Anggaran merupakan bagian yang sangat penting dalam suatu perusahaan atau instansi, dimana fungsinya untuk mengetahui keadaan keuangan suatu perusahaan atau instansi. Laporan realisasi ini merupakan salah satu alat ukur untuk melihat implementasi dari kebijakan pelaksanaan pengelolaan keuangan suatu daerah/desa dalam upaya mewujudkan pelayanan publik yang optimal serta upaya dalam mendorong pembangunan ekonomi daerah/desa (Rukayah, Kusumawati, \& Afriani, 2017).

\section{METODE KEGIATAN}

Pada kegiatan penelitian dan pengabdian kepada masyarakat ini, dilakukan analisis realisasi anggaran untuk menilai efektivitas dan efisiensi kinerja Pemerintah Desa Kalikurmo Kecamatan Bringin Kabupaten Semarang Provinsi Jawa Tengah menggunakan metode deskriptif kuanlitatif yang mendeskripsikan data apa adanya dan menjelaskan data atau kejadian dengan kalimat penjelasan secara kualitatif.

\section{Waktu dan Tempat}

Tempat dilakukannya penelitian adalah Kantor Pemerintah Desa Kalikurmo, Kecamatan Bringin, Kabupaten Semarang, Provinsi Jawa Tengah, Indonesia. Pengumpulan data penelitian Pemerintah Desa Kalikurmo, Kecamatan Bringin, Kabupaten Semarang di mulai pada Bulan Mei 2019.

\section{Metode Pengumpulan Data}

Metode pengumpulan data dilakukan melalui observasi yaitu suatu cara pengumpulan data yang dilakukan melalui pengamatan secara langsung terhadap obyek yang ingin diteliti serta melakukan pencatatan terhadap dokumendokumen yang dibutuhkan seperti laporan Anggaran Pendapatan dan Belanja Pemerintah Desa Kalikurmo tahun anggaran 2016-2018. Data yang digunakan dalam penelitian ini adalah data kuantitatif. Data kuantitatif adalah data yang diukur dalam suatu skala numerik atau angka- angka. Sumber data yang digunakan dalam penelitian adalah data sekunder dan primer. Dimana data diperoleh atau dikumpulkan, yang berupa data dokumentasi dan arsip-arsip resmi. Data ini bersumber dari Dokumen Laporan Realisasi Anggaran Belanja Pemerintah Desa Kalikurmo, Kecamatan Bringin, Kabupaten Semarang.

\section{Metode Analisis Data}

Analisis data yang digunakan adalah secara deskriptif kuanlitatif yaitu dengan cara mengumpulkan data, disusun, dienterprestasikan dan dianalisis sehingga dapat memberikan kesimpulan yang jelas dan objektif terhadap masalah yang ada yaitu mengenai kinerja Pemerintah Desa Kalikurmo, Kecamatan Bringin, Kabupaten Semarang yang dilihat dari segi efisisensi dan efektivitas laporan relisasi anggaran.

Untuk dapat mengetahui dan mengukur tingkat efektivitas pelaksanaan anggaran belanja kinerja Pemerintah Desa Kalikurmo, Kecamatan Bringin, Kabupaten Semarang, maka digunakan rumus (Mohamad Mahsun, 2013):

$$
\begin{array}{cc}
\text { Efektifitas } & \frac{\text { iealisasi Penerimaan PAD }}{\text { Target Penerimaan }} \times 100 \% \\
& \text { PAD }
\end{array}
$$

Keputusan Menteri Dalam Negeri Nomor 690.900-327 tahun 1996, kriteria tingkat efektifitas anggaran belanja sebagai berikut :

1. Jika hasil perbandingan lebih dari $100 \%$, maka anggaran belanja dikatakan sangat efektif.

2. Jika hasil pencapaian antara $90 \%-100 \%$, maka anggaran belanja dikatakan efektif.

3. Jika hasil pencapaian antara $80 \%-90 \%$, maka anggaran belanja dikatakan cukup efektif.

4. Jika hasil pencapaian antara $60 \%-80 \%$, maka anggaran belanja dikatakan kurang efektif.

5. Jika hasil pencapaian dibawah $60 \%$, maka anggaran belanja dikatakan tidak efektif

Perhitungan Tingkat Efisiensi

Pada dasarnya efisiensi menunjukkan pengukuran pencapaian output yang maksimum dengan penggunaan sumber daya dan dana yang serendah-rendahnyanya. Maka digunakan rumus sebagai berikut (Mohamad Mahsun, 2013):

$$
\text { Efisiensi }=\frac{\text { Realisasi Belanja }}{\text { Anggaran Belanja }} \times 100 \%
$$


Keputusan Menteri Dalam Negeri Nomor 690.900-327 tahun 1996, kriteria tingkat efisiensi anggaran belanja sebagai berikut:

1. Jika hasil perbandingan lebih dari $100 \%$, maka anggaran belanja dikatakan tidak efisien.

2. Jika hasil pencapaian antara $90 \%-100 \%$, maka anggaran belanja dikatakan kurang efisien.

3. Jika hasil pencapaian antara $80 \%-90 \%$, maka anggaran belanja dikatakan cukup efisien.

4. Jika hasil pencapaian antara $60 \%-80 \%$, maka anggaran belanja dikatakan efisien.
5. Jika hasil pencapaian dibawah $60 \%$, maka anggaran belanja dikatakan sangat efisien.

\section{HASIL DAN PEMBAHASAN}

\section{Analisis Efektivitas}

Tingkat Efektivitas Penerimaan PAD Pemerintah Desa Kalikurmo Kecamatan Bringin Kabupaten Tahun Anggaran 2016-2018 diukur menggunakan rasio efektivitas dari Laporan Realisasi Anggaran Pemerintah Desa Kalikurmo yang diuraikan sebagai berikut:

Tabel 1. Laporan Realisasi Anggaran Tahun Anggaran 2016-2018

\begin{tabular}{ccccc}
\hline Tahun & Target & Realisasi & Tingkat Efektivitas & Kriteria \\
\hline 2016 & 154.750 .000 & 154.750 .000 & $100 \%$ & Sangat Efektif \\
2017 & 170.228 .000 & 170.228 .000 & $100 \%$ & Sangat Efektif \\
2018 & 145.460 .500 & $145 . .460 .500$ & $100 \%$ & Sangat Efektif \\
\hline
\end{tabular}

Tabel 1 menunjukkan bahwa selama periode tahun anggaran 2016-2018, tingkat efektivitas penerimaan PAD bersifat tetap atau stabil dari tahun ke tahun. Pada tahun 2016 Pemerintah Desa Kalikurmo Kecamatan Beringin
Kabupaten Semarang memiliki rata-rata pelaksanaan anggarannya sudah masuk pada kriteria efektif. Dimana perbandingan antara target dan realisasi semakin mendekati $100 \%$.

Tabel 2. Tingkat Efisiensi Anggaran Belaja Pemerintah Desa Kalikurmo

\begin{tabular}{ccccc}
\hline Tahun & Target & Realisasi & Tingkat Efisien & Kriteria \\
\hline 2016 & 973.531 .000 & 968.951 .000 & $99,5 \%$ & Kurang Efisien \\
2017 & 1.336 .680 .000 & 1.336 .680 .000 & $100 \%$ & Kurang Efisien \\
2018 & 1.528 .137 .500 & 1.509 .801 .100 & $98,8 \%$ & Kurang Efisien \\
\hline
\end{tabular}

Berdasarkan pada tabel 1, hasil perhitungan perbandingan penerimaan PADesa dan target PADesa, maka rasio efektivitas APBDesa dapat diketahui. Rasio efektivitas APBDesa untuk tahun 2016-2018 berada pada angka yang sama sebesar $100 \%$. Secara rata-rata kecenderungan efektivitas PADesa Kalikurmo dari tahun 2016-2018 sebesar $100 \%$ pada kategori sangat efektif. Hal itu menunjukkan bahwa kinerja APBDesa Kalikurmo dalam kriteria sangat efektif.

Pada tahun 2016-2017 PADesa mengalami kenaikan yang signifikan yang berasal dari hasil aset usaha sebesar Rp. 300.000 dan swadaya, partisipasi dan gotong royong sebesar $\mathrm{Rp}$. 17.378.000. Dan pada tahun anggarang 2017-2018 mengalami penurunan yang berasal dari swadaya, partisipasi dan gotong royong sebesar Rp. 23.168.000. Dari tingkat efektivitas perkembangan kinerja keuangan APBDesa Kalikurmo dapat disimpulkan bahwa perkembangan kinerja keuangan stagnan selama 3 (tiga) tahun, hal tersebut menunjukkan perkembangan yang baik dalam pengelolaan keuangan desa.

\section{Analisis Efisiensi}

Tabel diatas menunjukkan tingkat efisiensi anggaran belanja Pemerintah Desa Kalikurmo Kecamatan Bringin Kabupaten Semarang yang berfluktuasi dari tahun ke tahun. Pada tahun 2016 tingkat efisiensi sebesar 99,5\% menjadi $100 \%$ pada tahun 2017. Dari sudut pandang efisiensi perubahan ini dipandang sebagai penurunan tingkat efisiensi, tetapi masih dalam kriteria yang kurang efisien. Pada tahun 2017 mengalami kenaikan tingkat efisiensi yang sebesar $1,2 \%$ menjadi 98,8\% dan memiliki kriteria kurang efisien. Secara keseluruhan, anggaran belanja Pemerintah Desa Kalikurmo Kecamatan Bringin Kabupaten 
Semarang tahun 2016 sampai tahun 2018 kurang efisien dengan tingkat efisiensi diatas $60 \%$.

Dapat diketahui, bahwa potensi yang dimiliki desa Kalikurmo saat ini berupa aset desa yaitu tanah bengkok yang dikelola oleh masyarakat dengan cara bagi hasil, yaitu $2 / 3$ untuk pengelola dan $1 / 3$ untuk desa, dan untuk tahun ini (2019) desa Kalikurmo sedang merintis program BUMDES , yang hasilnya nanti akan keluar pada tahun 2020. Hasil dari tanah bengkok yang telah dibagi hasil digunakan untuk membantu menyelenggarakan kegiatan desa yang menunjang kegiatan sosial seperti kegiatan yang ditujukan untuk kesejahteraan masyarakat. Penghasilan tanah bengkok di Desa Kalikurmo belum dapat dikatakan sesuai dengan standar yang berlaku karena penghasilan yang masih sedikit dan kurang mencukupi. Hasil dari tanah bengkok dari tahun ke tahun tidak selalu sama, ini disebabkan karena panen yang dihasilkan bagus maka prosentasenya akan bernominal besar, dan sebaliknya jika hasil panen yang diperoleh jelek maka prosentase nominal yang dihasilkan akan sedikit, sesuai dengan realita dilapangan.

Hasil analisa efisiensi tahun 2016-2018 pada tabel 2 menunjukkan bahwa kinerja pengelolaan APBDesa Kalikurmo dengan perbandingan realisasi belanja dan target belanja tidak efisien, pada tahun 2016 sebesar 99,5\%, pada tahun 2017 mengalami penurunan menjadi 100\%, dan pada tahun 2018 mengalami penurunan menjadi 98,8\% menunjukkan kinerja yang kurang efisien karena pemerintah desa dianggap tidak dapat menghemat dalam realisasi belanja. Namun, pada dasarnya kecenderungan yang tidak efisien pada Pemerindah desa Kalikurmo disebabkan oleh perhitungan alokasi keuangan yang digunakan untuk membiayai pembangunan dan aktivitas pemerintah desa tidak cermat dalam mengkalkulasi kapasitas keuangan desa.

Dapat dilihat dari laporan realisasi anggaran pada belanja pemerintah desa Kalikurmo tahun 2017 dengan jumlah target belanja Rp. 133.680.000 dengan jumlah realisasi belanja yang sama maka dianggap pemerintah desa kalikurmo tidak bisa menghemat belanja atau kurang meminimalisir anggaran belanja dalam mengalokasikannya. Selama periode tahun anggaran 2016-2018, rata-rata tingkat efisiensi APBDesa Kalikurmo memiliki kecenderungan tidak efisien, dengan tingkat efisiensi antara 90\%-100\% yaitu sebesar 99,43\%. Hasil penelitian ini menunjukkan bahwa kinerja APBDesa Kalikurmo dalam kriteria tidak efisien.

Perkembangan kinerja keuangan APBDesa dapat disimpulkan bahwa tingkat efisiensi terus mengalami kenaikan dan penurunan setiap tahun dan pada tahun 2016-2017 naik sebesar 0,5\%, pada tahun 2017-2018 turun sebesar 1,2, hal tersebut menunjukkan keadaan yang lebih baik dalam pengelolaan keuangan desa meskipun APBDesa belum dapat dikatakan cukup atau efisien.pembahasan memaparkan hasil pengolahan data, menginterpretasikan penemuan secara logis, mengaitkan dengan sumber rujukan yang relevan.

\section{Referensi Terdahulu}

Hasil penelitian dari (Waney, Saerang, \& Alexander, 2018) didapat bahwa tingkat efektivitas anggaran belanja tidak tetap dari tahun ketahun, dari yang cukup efektif hingga peningkatan yang efektif. Pada tahun 2012 89,93\% dikatakan cukup efektif, selanjutnya tahun 2013 94,61\%, sampai tahun 2014 93,78\% ditahun 2015 90,57 \% dan ditahun 2016 terjadi sedikit peningkatan menjadi 94,98\% masih tetap efektif. Tingkat efisiensi dari anggaran belanja pada Dinas Pertanian dan Peternakan Provinsi Sulawesi Utara yang tidak tetap tahun ke tahun. Pada tahun 2012 40,19\% dan tahun 2013 56,53\%. Pada tahun 2014 45,51\% dan tahun 2015 40,75\% dan ditahun 2016 menjadi $57,70 \%$ tapi masih masuk dalam kriteria sangat efisien karena masih dibawah 60\%. Berbeda dengan penelitian ini, dimana hasil perhitungan rasio efektifitas Desa Kalikurmo tahun 2016-2018 selalu stabil dengan kriteria sangat efektif. Dan jika dilihat dari hasil rasio efisiensinya maka pemerintah desa Kalikurmo dirasa masih terlalu boros sehingga menghasilkan kriteria kurang bagus yang berkisar dalam prosentase $90 \%-100 \%$.

Penelitian mengenai keterkaitan anggaran dengan kinerja instansi sektor publik sudah banyak dilakukan sebelumnya. Seperti dalam penelitian (Yunianti, 2015) yang meneliti tentang Analisis Efisiensi dan Efektivitas Anggaran Pendapatan dan Belanja Desa (APBDesa). Penelitian tersebut merupakan penelitian deskriptif kualitatif yang menggunakan data primer dan data sekunder. Lalu untuk teknik data yang digunakan tersebut ialah 
teknik analisis rasio untuk mengukur kinerja keuangan pemerintah. Dan hasil penelitian yang didapat dalam penelitian tersebut menunjukkan bahwa efisiensi penyelenggaraan APBDesa menunjukkan bahwa rasio efisiensi desa keuangan rata-rata adalah $103,12 \%$ dengan kategori tidak efisien tahun 2010 - 2013. Rasio efektivitas desa keuangan rata-rata adalah $125,75 \%$ dengan kecenderungan untuk menjadi sangat efektif kategori tahun 2010 - 2013. Berbeda dengan penelitian ini, dimana hasil perhitungan rasio efektivitas anggaran pendapatan tahun 2016-2018 pada kinerja Pemerintah Desa Kalikurmo, Kecamatan Bringin, Kabupaten Semarang dianggap sangat efektif dengan kriteria $100 \%$. Sementara hasil perhitungan efisiensi anggaran belanja, pada tahun 2016-2018 Pemerintah Desa Desa Kalikurmo, Kecamatan Bringin, Kabupaten Semarang dianggap kurang efisien. Dapat dilihat dalam penghitungan efisiensi anggaran belanja, pada 2016-2018 berada di kisaran 90\% -100\%.

Penelitian oleh (Sumenge, 2013) mengatakan bahwa tingkat efektifitas tertinggi terjadi pada 2010 dan yang terendah terjadi pada 2011. Pelaksanaan anggaran belanja tahun 2008, 2009, 2010 dan 2012 dikatakan efektif, tetapi pada tahun 2011 tingkat efektifitasnya masih kurang karena realisasi anggaran belanja memiliki perbedaan yang jauh dengan target anggaran belanja. Perbedaan ini terjadi karena ada beberapa kegiatan yang dianggarkan, tapi tidak dilaksanakan. Tetapi untuk kegiatan lain yang telah dianggarkan sudah efektif. BAPPEDA Minahasa Selatan menilai ketika kegiatan yang diprogramkan sudah terealisasi dan sesuai dengan yang diharapkan, maka kegiatan tersebut dikatakan efektif. Pelaksanaan anggaran Belanja BAPPEDA Tahun 2008 - 2012, secara keseluruhan sudah diolah secara efisien. Pelaksanaan anggaran belanja tahun 2008 sampai 2011, dikategorikan sangat efisien hanya saja tahun 2012 dikategorikan efisien. Berbeda dengan penelitian ini, dimana, tingkat efektivitas kinerja keuangan tahun 2016 2018 memiliki kecenderungan sangat efektif karena realisasi PADesa Kalikurmo sesuai dengan target PADesa Kalikurmo yaitu dengan rata-rata tingkat efektivitas sebesar 100\%. Dan tingkat efisiensi kinerja keuangan tahun 2016 - 2018 memiliki kecenderungan kurang efisien. Dan secara keseluruhan kinerja keuangan tidak efisien dengan rata-rata tingkat efisiensi diantara $90 \%$ - 100\% yaitu sebesar $99,43 \%$.

Penelitian oleh (Machmud, Kawung, \& Rompas, 2014) yang menyatakan bahwa hasil perhitungan untuk rasio efektifitas, kemampuan daerah di Sulawesi Utara didalam menjalankan tugasnya kurang stabil karena masih mengalami rasio yang naik turun. Kinerja Pemerintah daerah di Provinsi Sulawesi Utara belum efektif karena efektifnya belum mencapai 1 (satu) atau 100 persen, kecuali untuk tahun 2012. Penelitian ini membahas tentang rasio keuangan yang terdiri dari rasio kemandirian keuangan daerah, rasio efektifitas dan rasio pertumbuhan. Berbeda dengan penelitian ini bahwa untuk perhitungan dalam rasio efektifitas sudah stabil dengan tingkatan sangat efektif. Dan dalam penelitian ini membahas tentang rasio keuangan yang terdiri dari rasio efektifitas dan rasio efisien.

Penelitian oleh (I Dewa Gde Bisma Dan Hery Susanto, 2010) mengatakan bahwa (1) berdasarkan analisis kinerja keuangan, secara umum provinsi NTB pada Tahun Anggaran 2003 2007 yang ditunjukkan oleh indikator kinerja keuangan, terdapat; Ketergantungan keuangan daerah yang Sangat Tinggi kepada Pemerintah Pusat sehingga tingkat Kemandirian daerah Sangat Kurang. Desentralisasi Fiskal yang dalam hafalan Menengah daripada ketergantungan finansial kepada Pemerintah pusat sangat tinggi. Efektivitas pengorganisasian APBD Sangat Efektif, tetapi Efisiensi pengorganisasian APBD menunjukkan hasilnya tidak efisien. (2) Dilihat dari indikasi kinerja PAD, kontribusi PAD (share) terhadap total pendapatan daerah Provinsi NTB pada Tahun Anggaran 2003-2007 masih rendah, tetapi pertumbuhan PAD tinggi. Meskipun PAD meningkat, tetapi jika dibandingkan dengan peningkatan anggaran daerah, maka proporsi peningkatan PAD sangat rendah. (3) Provinsi NTB memiliki kemampuan finansial yang tinggi. Namun, tingginya kemampuan keuangan daerah Provinsi NTB disebabkan oleh banyak subsidi atau pembagian keuangan yang diberikan oleh Pemerintah Pusat melalui Dana Perimbangan. Berbeda dengan penelitian ini bahwa untuk perhitungan dalam rasio efektifitas sudah stabil dengan kriteria sangat efektif. Dan dalam penelitian ini rasio efisien menunjukkan bahwa rasio ini kisaran $90 \%-100 \%$. 
Penelitian oleh (Elim \& Liando, 2016) mengatakan bahwa hasil penelitiannya ialah belanja pada Laporan Realisasi Anggaran untuk tahun anggaran 2011-2014 menunjukkan bahwa kinerja belanja Pemerintah kabupaten Kepulauan Sangihe dinilai baik dan terus melakukan perbaikan setiap tahun dalam pemanfaatan realisasi belanja. Pertumbuhan belanja mulai terlihat pada tahun anggaran 2013 dan 2014 dibandingkan dengan tahun anggaran 2011 dan 2012. Dan hasil perhitungan rasio efisiensi belanja menunjukkan bahwa Pemerintah Kabupaten Kepulauan Sangihe dapat melakukan penghematan anggaran yang terlihat stabil. Peningkatan pertumbuhan belanja ini disebabkan oleh adanya pertumbuhan penduduk setiap tahunnya dan juga dipengaruhi oleh besarnya inflasi. Sedangkan dalam penelitian ini belanja pada Laporan Realisasi Anggaran untuk tahun anggaran 2016-2018 memiliki kecenderungan sangat efektif karena realisasi PADesa Kalikurmo sesuai dengan target PADesa Kalikurmo yaitu dengan rata-rata tingkat efektivitas sebesar $100 \%$. Dan untuk hasil rasio efisiensi tingkat efisiensi kinerja keuangan tahun 2016 - 2018 memiliki kecenderungan kurang efisien. Namun secara keseluruhan kinerja keuangan tidak efisien dengan rata-rata tingkat efisiensi diantara $90 \%$ - $100 \%$ yaitu sebesar $99,43 \%$. Penelitian dari (Rahmayati, 2016) menunjukkan bahwa tingkat efektivitas pemerintah kabupaten Sukoharjo dalam mengelola pendapatan asli daerah mengalami peningkatan dari 107,71\% tahun 2011 menjadi $116,44 \%$ pada tahun 2012 . Walaupun pada tahun 2013 mengalami penurunan yakni sebesar $113,20 \%$, tetapi masih termasuk kriteria efektif. Hal ini menunjukkan ini menunjukkan bahwa kinerja keuangan Pemerintah Kota Sukoharjo masih belum optimal. Meskipun pengelolaan Pendapatan Daerah efektif dan efisien, tetapi tingkat kemandirian daerah masih sangat rendah. Ini terlihat dari jumlah bantuan dari pendapatan pusat dan provinsi dibandingkan dengan kabupaten Sukoharjo setempat yang asli. Selain itu, penggunaan dana masih belum seimbang karena sebagian besar dana digunakan untuk pengeluaran operasional daripada belanja modal. Sedangkan dalam penelitian ini hanya membahas tentang tingkat efektifitas dan efisiensi. Dengan hasil bahwa penelitian ini menunjukkan rasio efektifitas sudah stabil dengan kriteria sangat efektif. Dan dalam penelitian ini rasio efisien menunjukkan bahwa rasio ini kisaran $90 \%-100 \%$.

Berdasarkan penelitian yang dilakukan oleh (Astuti, 2015) dengan judul Analisis Pengaruh Kinerja Keuangan Terhadap Pertumbuhan Ekonomi Dan Dampaknya Terhadap Pengangguran Dan Kemiskinan (Studi Pada Kabupaten Dan Kota Di Pulau Jawa Periode 2007-2011). Hasil tes menunjukkan bahwa rasio kemandirian dan rasio efektivitas berpengaruh positif pada pertumbuhan ekonomi, sedangkan rasio efisiensi tidak berdampak signifikan terhadap pertumbuhan ekonomi. Hasil pengujian pengaruh pertumbuhan ekonomi terhadap pengangguran dan kemiskinan menunjukkan bahwa pertumbuhan ekonomi memiliki efek negatif yang signifikan terhadap pengangguran, namun tidak signifikan terhadap kemiskinan. Berbeda dengan penelitian ini, dimana hasil perhitungan dari tingkat efektifitas sebesar $100 \%$ dengan kriteria sangat efektif. Dan jika dihitung dengan tingkat efisiensi maka menghasilkan prosentase dalam kisaran 90\%$100 \%$, dengan ini menunjukkan bahwa pemerintah desa Kalikurma kurang baik dalam melakukan belanja.

\section{KESIMPULAN}

Tingkat efektivitas kinerja keuangan tahun 2016 -2018 memiliki kecenderungan sangat efektif karena realisasi PADesa Kalikurmo sesuai dengan target. Tingkat efisiensi kinerja keuangan tahun 2016 - 2018 memiliki kecenderungan kurang efisien. Berdasarkan naik-turunnya perkembangan kinerja keuangan APBDesa Kalikurmo menunjukkan bahwa kinerja pendapatan berfluktuatif selama 3 (tiga) tahun. Apabila dilihat dari rasio efektivitas, maka perkembangan kinerja keuangan pemerintah desa desa Kalikurmo sangat baik, karena pada tahun 2016-2018 mengalami tingkat efektifitas yang stagnan yaitu sebesar $100 \%$. Berdasarkan tingkat efisiensi perkembangan kinerja keuangan pemerintah desa menunjukkan kenaikan dan penurunan setiap tahun, tahun 2016 sebesar 99,5\%, tahun 2017 turun menjadi 100\%, dan tahun 2018 naik menjadi $98,8 \%$. 


\section{UCAPAN TERIMAKASIH}

Ucapan terimakasih kami sampaikan kepada Bapak Saiful Anwar, M.Acc dan Bapak Nur Kabib, S.E., M.S.I., M.Pd.AK yang sudah membimbing kami dalam Penelitian ini, serta tak lupa kai ucapkan terimakasih kepada teman-teman serta pihak yang terkait dalam Penelitian ini.

\section{DAFTAR PUSTAKA}

Astuti, W. (2015). Analisis Pengaruh Kinerja Keuangan Terhadap Pertumbuhan Ekonomi Dan Dampaknya Terhadap Pengangguran Dan Kemiskinan (Studi Pada Kabupaten Dan Kota Di Pulau Jawa Periode 2007-2011). Jurnal EBBANK, 6(1), 1-18.

Basariyah, S. (2017). Analisis Efektivitas dan Efisiensi Pelaksanaan Anggaran Belanja Pada Badan Pemberdayaan Masyarakat dan Pemerintahan Desa (BPMPD) Daerah Provinsi Sulawesi Tengah. Jurnal Katalogis, 5(6), 63.

Boedi, S. (2012). Analisis Kinerja Keuangan pada APBD Pemerintah Kabupaten Banjar Kalimantan Selatan. Jurnal Spread, 2(2), 183190.

Elim, I., \& Liando, G. (2016). Analisis Kinerja Belanja Dalam Laporan Realisasi Anggaran (Lra) Pada Dinas Pendapatan Pengelolaan Keuangan Dan Aset Daerah Kabupaten Kepulauan Sangihe. Jurnal Riset Ekonomi, Manajemen, Bisnis Dan Akuntansi, 4(1), 1473-1484.

I Dewa Gde Bisma Dan Hery Susanto. (2010). Evaluasi Kinerja Keuangan Daerahpemerintah Provinsi Nusa Tenggara Barattahun Anggaran 2003-2007. Gane SwaraEdisi Khusus, 4(3), 75-86.

Indonesia, R. (2004). Undang Undang nomor 32 Tahun 2004 tentang Pemerintah Daerah. Jakarta: Sekretariat Negara.

Machmud, M., Kawung, G., \& Rompas, W. (2014). Analisis Kinerja Keuangan Daerah Di Provinsi Sulawesi Utara Tahun 2007-2012. Jurnal Berkala Ilmiah Efisiensi, 14(2), 1-13.

Mamuaja, B. (2016). Analisis Efektivitas Penerapan Sistem Pengendalian Intern Terhadap Kinerja Instansi Pemerintah di Dinas Pendapatan
Kota Manado. Jurnal EMBA, 4(1), 165-171.

Mardiasmo. (2002). Akuntansi Sektor Publik. Yogyakarta: Andi Ofset.

Rahmayati, A. (2016). Analisis Kinerja Keuangan Pemerintah Daerah Kabupaten Sukoharjo Tahun Anggaran 2011-2013. Jurnal EKA CIDA, 1(1), 40-54.

Roland Gerald Tooy, David Paul Elia Saerang, L. M. (2016). Analisis Efisiensi dan Efektivitas Laporan Realisasi Anggaran di Badan Perencanaan Pembangunan dan Penelitian Pengembangan (Bappelitbang) Kabupaten Minahasa Utara MINAHASA UTARA. Jurnal Berkala Ilmiah Efisiensi, 16(4), 659-671.

Ropa, M. O. (2016). Analisis Kinerja Keuangan Pemerintah Kabupaten Minahasa Selatan. Jurnal EMBA, 4(2), 739.

Rukayah, Kusumawati, N., \& Afriani, R. I. (2017). Analisis Laporan Realisasi Anggaran Dengan Menggunakan Rasio Efektivitas Dan Rasio Efisiensi Pada Kantor Badan Perijinan Terpadu Dan Penanaman Modal Kabupaten Serang. Jurnal Akuntansi, 4(2), 1-11.

Sinambela, E., \& Pohan, K. R. A. (2016). Analisis Kinerja Anggaran Pendapatan dan Belanja Daerah Pada Pemerintah Provinsi Sumatera Utara. Jurnal Riset Akuntansi Dan Bisnis, 16(1).

https://doi.org/10.1017/СB09781107415324 .004

Sumenge, A. (2013). Analisis Efektifitas Dan Efisiensi Pelaksanaan Anggaran Belanja Badan Perencanaan Pembangunan Daerah (Bappeda) Minahasa Selatan. Jurnal Riset Ekonomi, Manajemen, Bisnis Dan Akuntansi, 1(3), 74-81.

Waney, C. K., Saerang, D. P. E., \& Alexander, S. W. (2018). Analisis Realisasi Anggaran Untuk Menilai Efektivitas Dan Efisiensi Kinerja Pemerintah Di Dinas Pertanian Dan Peternakan Provinsi Sulawesi Utara. Going Concern : Jurnal Riset Akuntansi, 13(02), 334-341. https://doi.org/10.32400/gc.13.02.19527.20 18

Yunianti, U. (2015). Analisis Efisiensi dan Efektivitas anggaran pendapatan dan belanja desa (APBDesa). Seminar Nasional Universitas PGRI Yogyakarta, (2009), 499. 